\title{
Analisis Kinerja Keuangan Baitul Mal Wattamwil Al-Ittihat di Pekanbaru
}

\author{
MASNUR \\ ***Fakultas Agama Islam (FAI) Universitas Islam Riau (UIR) \\ Jl. Kaharuddin Nasution No.113 Perhentian Marpoyan Pekanbaru 28284
}

\begin{abstract}
Abstrak: Kinerja keuangan BMT merupakan suatu gambaran tentang kondisi keuangan suatu BMT yang dianalisis dengan metode analisis keuangan, sehingga dapat diketahui mengenai baik buruknya keadaan keuangan suatu perusahan yang mencerminkan prestasi kerja dalam periode tertentu. Kinerja keuangan yang baik dapat dinilai dari hasil analisis yang memperoleh presntasi yang sesuai dengan standar yang telah ditetapkan. Rumusan masalah yang dihasilkan adalah bagaimana kinerja keuangan pada BMT AL ITIHAD pekanbaru dalam meningkatkan penerimaannya. Hasil penelitian menunjukkan bahwa keseluruhan analisis yang dilakukan menghasilkan angka ratio yang stabil. Kinerja keuangan yang terjadi pada pendapatan BMT Al-Ittihad Pekanbaru cukup stabil dalam hal efesiensi biaya disebabkan jika pengeluaran (biaya) operasional meningkat maka pendapatanpun meningkat dan sebaliknya jika pengeluaran (biaya) operasional menurun maka pendapatanpun menurun. Hasil penelitian menunjukan Sisa hasil usaha diperoleh dari pendapatan dikurangi dengan pengeluaran (biaya) operasional. Stabilitas sisa hasil usaha BMT Al-ittihat Pekanbaru terbukti setiap tahun meningkat, artinya pendapatan BMT Al-Ittihad Pekanbaru setiap tahun selalu lebih besar dari pada pengeluaran.Sisa hasil usaha selama empat tahun terakhir juga dapat dipertahankan stabilitasnya seperti pada tahun 2011 laba bersih yang diperoleh relatif kecil dari tahun 2012 tetapi dibarengi dengan biaya kecil pula sehingga laba yang dihasilkan juga relatif stabil. Pada tahun 2012 sisa hasil usaha mengalami peningkatan dari tahun 2011sebesar 0,24\% tetapi dibarengi dengan peningkatan biaya maka laba yang dihasilkan juga relatif stabil. Pada 2013 sisa hasil usaha mengalami pendekatan sebesar $0,21 \%$ tetapi di barengi dengan peningkatan biaya maka laba yang dihasilkan juga relatif stabil. Pada tahun 2014 laba bersih mengalami kenaikan sebesar 0,26\% dibarengi dengan peningkatan biaya maka laba yang dihasilkan juga relatif stabil.
\end{abstract}

\section{PENDAHULUAN}

Pada umumnya, setiap kegiatan usaha apapun bentuknya bertujuan untuk memperoleh laba atau keuntungan. Banyak cara yang dilakukan oleh pegiat usaha baik berlandaskan penerapan ekonomi konvensional maupun ekonomi syariah dengan tujuan untuk memperoleh laba atau keuntungan. Salah satu badan usaha yang berupaya untuk mengembangakan usaha secara syariah yaitu Baitul Mal wat Tamwil (BMT).

Baitul Mal wat Tamwil merupakan lembaga keuangan mikro syariah yang menjadi wadah bagi umat Islam untuk menerapkan nilai-nilai ajaran Islam, saling membantu antara sikaya dan orang yang memerlukan tambahan modal, mendidik umat jujur dalam berhutang, mau mencatat hutangnya, jujur dalam berbinis dan disiplin (Buchari Alma, 2005: 25). Allah SWT berfirman:

Jurnal Al-hikmah Vol. 13, No. 2, Oktober 2016 ISSN 1412-5382 


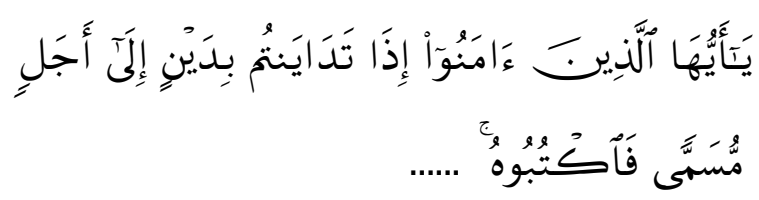

Artinya : "Hai orang-orang yang beriman, apabila kamu bermu'amalah tidak secara tunai untuk waktu yang ditentukan, maka hendaklah kamu menulisnya..." (QS: al-Baqarah, 2 : 282)

Bersama BMT ini jelas masyarakat didorong untuk melakukan usaha perbaikan ekonomi umat yang selama ini memang membutuhkan peningkatan hidup yang lebih baik dan itu bisa dilakukan dengan mengamalkan ajaran Al-Quran, tentang prinsip tolongmenolong, mendorong kemajuan ekonomi mikro, mendidik umat Islam agar bekerja dengan manajemen yang baik, penuh kejujuran dan disiplin. Menjalin kerja sama saling membantu meningkatkan usaha antara yang mampu dengan yang membutuhkan modal. Allah SWT berfitman dalam :

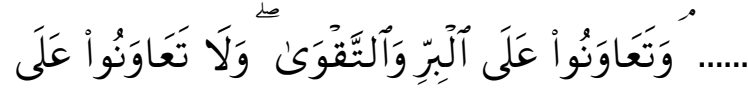

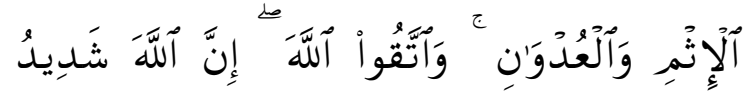

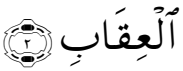

Artinya : Tolong menolonglah kamu dalam mengerjakan kebaikan dan takwa, dan jangan tolong menolong dalam berbuat dosa dan pelanggaran. Dan bertakwalah kamu kepada Allah, sesungguhnya Allah amat berat siksaNya. (QS: alMaidah, $5: 2$ ).

Banyak BMT yang telah beroperasi dalam upaya gerakan perbaikan ekonomi rakyat. Salah satunya adalah BMT Al-Ittihad yang berada di kota Pekanbaru. Jenis usaha yang dilakukan seperti simpanan, pembiayaan (pinjaman) dan sektor ril yaitu perdagangan, serta usaha lainnya yang layak, menguntungkan dalam jangka panjang dan tidak mengganggu dalam program jangka pendek. Dalam rangka mengelola usahanya pengurus mengangkat beberapa karyawan untuk melanjutkan usahanya yang setiap bulannya diberikan gaji tetap dan isentif yang lainnya.

Penerimaan kotor BMT Al-Ittihad setiap tahun bukunya mengalami peningkatan hal ini disebabkan karena setiap unit usaha yang ada memperoleh laba, akan tetapi laba bersih (Sisa Hasil Usaha) setiap tahunnya tidak stabil dan cenderung berfluktuasi. Hal ini dikarenakan penerimaan dari setiap unit usaha tidak dibarengi dengan efisiensi dalam penggunaan biaya.

Melihat perkembangan pada kegiatan usaha BMT Al-Ittihad yang telah berhasil dalam mengembangkan usahanya hingga memiliki beberapa cabang,oleh karena itu, melalui penelitian ini penulis tertarik untuk menganalisis kinerja keuangan yang ada di BMT Al-Ittihad Pekanbaru.

\section{KONSEP TEORI}

\section{Hakikat Baitul Mal wa Tamwil (BMT)}

Baitul Mal berasal dari bahasa Arab bait yang berarti rumah, dan al-mal yang berarti harta. Jadi secara etimologis (ma'na lughawi) Baitul Mal berarti rumah untuk mengumpulkan atau menyimpan harta (Dahlan, 1999).

Adapun secara terminologis (ma'na ishtilahi), sebagaimana uraian Abdul Qadim Zallum (1983) dalam kitabnya Al Amwaal Fi Daulah Al Khilafah, Baitul Mal adalah suatu lembaga atau pihak (Arab: al jihat) yang mempunyai tugas khusus menangani segala harta umat, baik berupa pendapatan maupun pengeluaran negara. Jadi setiap harta baik berupa 
tanah, bangunan, barang tambang, uang, komoditas perdagangan, maupun harta benda lainnya di mana kaum muslimin berhak memilikinya sesuai hukum syara' dan tidak ditentukan individu pemiliknya, walaupun telah tertentu pihak yang berhak menerimanya, maka harta tersebut menjadi hak Baitul Mal, yakni sudah dianggap sebagai pemasukan bagi Baitul Mal. Secara hukum, harta-harta itu adalah hak Baitul Mal, baik yang sudah benar-benar masuk ke dalam tempat penyimpanan Baitul Mal maupun yang belum.

Baitul Mal wa Tamwil dalam bahasa Arab disingkat menjadi BMT adalah Kelompok Swadaya Masyarakat (KSM) sebagai lembaga ekonomi rakyat yang berupaya mengembangkan usahausaha produktif dan investasi dengan sistem bagi hasil untuk meningkatkan kualitas ekonomi pengusaha kecil bawah dan kecil dalam rangka upaya pengentasan kemiskinan.

Baitul Mal wa Tamwil (BMT) adalah balai usaha mandiri terpadu yang isinya berintikan bayt al-mal wa altamwil dengan kegiatan mengembangkan usaha-usaha produktif dan investasi dalam meningkatkan kualitas kegiatan ekonomi pengusaha kecil bawah dan kecil dengan antara lain mendorong kegiatan menabung dan menunjang pembiayaan kegiatan ekonominya.(Djazuli dan Janwari, 2002 : 183) Selain itu, baitul mal wa tamwil juga bisa menerima titipan zakat, infak dan sedekah, serta menyalurkannya sesuai dengan peraturan dan amanatnya.(PINBUK, t.t : 1 )

Baitul Mal wa Tamwil adalah lembaga ekonomi atau keuangan syariah non perbankan yang sifatnya informal. Disebut informal karena lembaga ini didirkan oleh Kelompok Swadaya Masyarakat (KSM) yang berbeda dengan lembaga keuangan perbankan dan lembaga keungan formal lainnya. (Djazuli dan Janwari, 2002 : 183)
$B M T$ adalah perpaduan antara kegiatan sosial dengan kegiatan bisnis. Baitul Mal adalah lembaga sosial yang menghimpun dana dari umat berupa ZIS dan sumber lainnya, serta menyalurkan kepada mustahiknya. Sedangkan Baitul Tamwil adalah aktivitas dalam bidang bisnis, yang memanfaatkan (mendayagunakan) dana masyarakat tersebut dalam bentuk pinjaman permodalan tanpa bunga atau dengan sistem bagi hasil. BMT merupakan wadah bagi umat Islam untuk menerapkan nilai-nilai ajaran Islam, dibidang muamalah yang saling membantu antara sikaya dan orang yang memerlukan tambahan modal, mendidik umat disiplin dalam mendayagunakan dana(Buchari Alma, 2005 : 25)

Dari pengertian itu dapat dipahami bahwa baitul mal wa tamwil suatu lembaga keuangan mikro syariah yang terdiri dari baitul mal dan baitul tamwil, bila dilihat dari fungsinya ada perbedaan yaitu baitul mal merupakan fungsi penghimpun dana dari umat berupa zakat, infak dan shadaqah atau dari sumber yang lain, sedangkan baitul tamwil fungsinya sebagai pengelola dana yang ada pada baitul mal dengan harapan dapat berkembang dan menjadi manfaat bagi umat, pengembangan institusi keuangan ini diadopsi dari bayt al-mal yang pernah dan sempat tumbuh dan berkembang pada masa Nabi saw dan Khulafa al-Rasyidin.

Oleh karena itu, keberadaan BMT selain bisa dianggap sebagai media penyalur pendayagunaan harta ibadah seperti zakat. infaq dan shadaqah, juga bisa dianggap sebagai institusi yang bergerak dibidang investasi yang bersifat produktif. Oleh karena itu, selain berfungsi sebagai lembaga keuangan, $B M T$ juga bisa berfungsi sebagai lembaga ekonomi. Sebagai lembaga keuangan ia bertugas menghimpun dana dari masyarakat dan menyalurkan dana kepada masyarakat 
yang memerlukan dana tersebut. Sebagai lembaga ekonomi ia juga berhak melakukan kegiatan ekonomi seperti perdagangan, industri dan pertanian.

\section{Sejarah Singkat Baitul Mal wa Tamwil (BMT) \\ BMT Pada Masa Rasulullah SAW (1-11 H/622-632 M)}

Baitul Mal sesungguhnya sudah ada sejak masa Rasulullah SAW, yaitu ketika kaum muslimin mendapatkan ghanimah (harta rampasan perang) pada Perang Badar (Zallum, 1983). Saat itu para shahabat berselisih paham mengenai cara pembagian ghanimah tersebut sehingga turun firman Allah SWT yang menjelaskan hal tersebut:
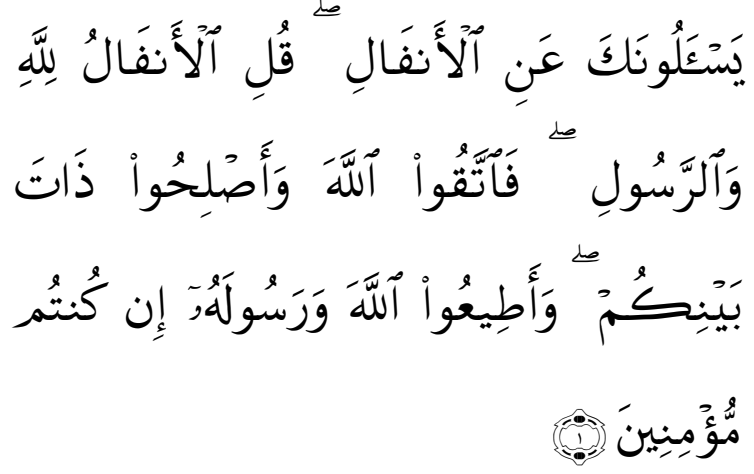

Artinya: "Mereka bertanya kepadamu (Muhammad) tentang (pembagian) harta rampasan perang. Katakanlah,'Harta rampasan perang itu adalah milik Allah dan Rasul, oleh sebab itu bertaqwalah kepada Allah dan perbaikilah hubungan di antara sesama kalian, dan taatlah kepada Allah dan Rasul-Nya jika kalian benar-benar orang-orang yang beriman." (QS Al Anfaal : 1).

Dengan ayat ini, Allah menjelaskan hukum tentang pembagian harta rampasan perang dan menetapkannya sebagai hak bagi seluruh kaum muslimin. Selain itu, Allah juga memberikan wewenang kepada Rasulullah SAW untuk membagikannya sesuai pertimbangan beliau mengenai kemaslahatan kaum muslimin. Dengan demikian, ghanimah Perang Badar ini menjadi hak bagi Baitul Mal, di mana pengelolaannya dilakukan oleh Waliyyul Amri kaum muslimin, yang pada saat itu adalah Rasulullah SAW sendiri, sesuai dengan pendapatnya untuk merealisasikan kemaslahatan kaum muslimin (Zallum, 1983).

Pada masa Rasulullah SAW ini, Baitul Mal lebih mempunyai pengertian sebagai pihak (al-jihat) yang menangani setiap harta benda kaum muslimin, baik berupa pendapatan maupun pengeluaran. Saat itu Baitul Mal belum mempunyai tempat khusus untuk menyimpan harta, karena saat itu harta yang diperoleh belum begitu banyak. Kalaupun ada, harta yang diperoleh hampir selalu habis dibagi-bagikan kepada kaum muslimin serta dibelanjakan untuk pemeliharaan urusan mereka. Rasulullah SAW senantiasa membagikan ghanimah dan seperlima bagian darinya (al-akhmas) setelah usainya peperangan, tanpa menunda-nundanya lagi. Dengan kata lain, beliau segera menginfakkannya sesuai peruntukannya masing-masing.

\section{BMT Pada Masa Khalifah Abu Bakar Ash Shiddiq (11-13 H/632-634 M)}

Pada tahun pertama Abu Bakar menjadi Khalifah (11 H/632 M), kegiatan Baitul Mal masih berlangsung seperti zaman Rasulullah. Jika datang harta kepadanya dari wilayah-wilayah kekuasaan Khilafah Islamiyah, Abu Bakar membawa harta itu ke Masjid Nabawi dan membagi-bagikannya kepada orangorang yang berhak menerimanya. Untuk urusan ini, Khalifah Abu Bakar telah mewakilkan kepada Abu Ubaidah bin Al Jarrah. Hal ini diketahui dari pernyataan Abu Ubaidah bin Al Jarrah saat Abu Bakar dibai'at sebagai Khalifah. Abu Ubaidah saat itu berkata kepadanya, 
Kemudian pada tahun kedua kekhilafahannya (12 H/633 M), Abu Bakar merintis embrio Baitul Mal dalam arti yang lebih luas. Baitul Mal bukan sekedar berarti pihak (al- jihat) yang menangani harta umat, namun juga berarti suatu tempat (al-makan) untuk menyimpan harta negara. Abu Bakar menyiapkan tempat khusus di rumahnya, berupa karung atau kantung (ghirarah), untuk menyimpan harta yang dikirimkan ke Madinah. Hal ini berlangsung sampai kewafatan beliau pada tahun $13 \mathrm{H} / 634 \mathrm{M}$.

$\mathrm{Abu}$ Bakar dikenal sebagai Khalifah yang sangat wara' (hati-hati) dalam masalah harta. Bahkan pada hari kedua setelah beliau dibai'at sebagai Khalifah, beliau tetap berdagang dan tidak mau mengambil harta umat dari Baitul Mal untuk keperluan diri dan keluarganya. Diriwayatkan oleh lbnu Sa'ad (w. 230 H/844 M), penulis biografi para tokoh muslim, bahwa Abu Bakar, yang sebelumnya berprofesi sebagai pedagang, membawa barang-barang dagangannya yang berupa bahan pakaian di pundaknya dan pergi ke pasar untuk menjualnya. Di tengah jalan, ia bertemu dengan Umar bin Khaththab. Umar bertanya, "Anda mau kemana, hai Khalifah?" Abu Bakar menjawab, "Ke pasar." Umar berkata, "Bagaimana mungkin Anda melakukannya, padahal Anda telah memegang jabatan sebagai pemimpin kaum muslimin?" Abu Bakar menjawab, "Lalu dari mana aku akan memberikan nafkah untuk keluargaku?" Umar berkata, "Pergilah kepada Abu Ubaidah (pengelola Baitul Mal), agar ia menetapkan sesuatu untukmu." Keduanya pun pergi menemui Abu Ubaidah, yang segera menetapkan santunan (ta'widh) yang cukup untuk Khalifah Abu Bakar, sesuai dengan kebutuhan seseorang secara sederhana, yakni 4000 dirham setahun yang diambil dari Baitul Mal.
Menjelang ajalnya tiba, karena khawatir terhadap santunan yang diterimanya dari Baitul Mal, Abu Bakar berpesan kepada keluarganya untuk mengembalikan santunan yang pernah diterimanya dari Baitul Mal sejumlah 8000 dirham. Ketika keluarga Abu Bakar mengembalikan uang tersebut setelah beliau meninggal, Umar berkata, "Semoga Allah merahmati Abu Bakar. Ia telah benar-benar membuat payah orang-orang yang datang setelahnya." Artinya, sikap Abu Bakar yang mengembalikan uang tersebut merupakan sikap yang berat untuk diikuti dan dilaksanakan oleh para Khalifah generasi sesudahnya (Dahlan, 1999).

\section{BMT Pada Masa Khalifah Umar bin Khaththab (13-23 H/634-644 M)}

Setelah Abu Bakar wafat dan Umar bin Khaththab menjadi Khalifah, beliau mengumpulkan para bendaharawan kemudian masuk ke rumah Abu Bakar dan membuka Baitul Mal. Ternyata Umar hanya mendapatkan satu dinar saja, yang terjatuh dari kantungnya.

Akan tetapi setelah penaklukan-penaklukan (futuhat) terhadap negara lain semakin banyak terjadi pada masa Umar dan kaum muslimin berhasil menaklukan negeri Kisra (Persia) dan Qaishar (Romawi), semakin banyaklah harta yang mengalir ke kota Madinah. Oleh karena itu, Umar lalu membangun sebuah rumah khusus untuk menyimpan harta, membentuk diwan-diwannya (kantor-kantornya), mengangkat para penulisnya, menetapkan gaji-gaji dari harta Baitul Mal, serta membangun angkatan perang. Kadang-kadang ia menyimpan seperlima bagian dari harta ghanimah di masjid dan segera membagi-bagikannya. Mengenai mulai banyaknya harta umat ini, Ibnu Abbas pernah mengisahkan: "Umar 
pernah memanggilku, ternyata di hadapannya ada setumpuk emas terhampar di hadapannya. Umar lalu berkata : "Kemarilah kalian, aku akan membagikan ini kepada kaum muslimin. Sesungguhnya Allah lebih mengetahui mengapa emas ini ditahan-Nya dari Nabi-Nya dan Abu Bakar, lalu diberikannya kepadaku. Allah pula yang lebih mengetahui apakah dengan emas ini Allah menghendaki kebaikan atau keburukan"

Selama memerintah, Umar bin Khaththab tetap memelihara Baitul Mal secara hati-hati, menerima pemasukan dan sesuatu yang halal sesuai dengan aturan syariat dan mendistribusikannya kepada yang berhak menerimanya. Dalam salah satu pidatonya, yang dicatat oleh lbnu Kasir (700-774 H/1300-1373 M), penulis sejarah dan mufasir, tentang hak seorang Khalifah dalam Baitul Mal, Umar berkata, "Tidak dihalalkan bagiku dari harta milik Allah ini melainkan dua potong pakaian musim panas dan sepotong pakaian musim dingin serta uang yang cukup untuk kehidupan sehari-hari seseorang di antara orangorang Quraisy biasa, dan aku adalah seorang biasa seperti kebanyakan kaum muslimin." (Dahlan, 1999).

\section{BMT Pada Masa Khalifah Utsman bin Affan (23-35 H/644-656 M)}

Kondisi yang sama juga berlaku pada masa Utsman bin Affan. Namun, karena pengaruh yang besar dan keluarganya, tindakan Usman banyak mendapatkan protes dari umat dalam pengelolaan Baitul Mal. Dalam hal ini, lbnu Sa'ad menukilkan ucapan Ibnu Syihab Az Zuhri (51-123 H/670-742 M), seorang yang sangat besar jasanya dalam mengumpulkan hadis, yang menyatakan, "Usman telah mengangkat sanak kerabat dan keluarganya dalam jabatan-jabatan tertentu pada enam tahun terakhir dari masa pemerintahannya. Ia memberikan khumus (seperlima ghanimah) kepada Marwan, yang kelak menjadi Khalifah ke-4 Bani Umayyah, memerintah antara 684-685 M, dari penghasilan Mesir serta memberikan harta yang banyak sekali kepada kerabatnya dan ia (Usman) menafsirkan tindakannya itu sebagai suatu bentuk silaturahmi yang diperintahkan oleh Allah SWT. Ia juga menggunakan harta dan meminjamnya dari Baitul Mal sambil berkata, "Abu Bakar dan Umar tidak mengambil hak mereka dari Baitul Mal, sedangkan aku telah mengambilnya dan membagibagikannya kepada sementara sanak kerabatku. Itulah sebab rakyat memprotesnya." (Dahlan, 1999).

\section{BMT Pada Masa Khalifah Ali bin Abi Thalib (35-40 H/656-661 M)}

Pada masa pemerintahan Ali bin

Abi Talib, kondisi Baitul Mal ditempatkan kembali pada posisi yang sebelumnya. Ali, yang juga mendapat santunan dari Baitul Mal, seperti disebutkan oleh lbnu Kasir, mendapatkan jatah pakaian yang hanya bisa menutupi tubuh sampai separo kakinya, dan sering bajunya itu penuh dengan tambalan.

Ketika berkobar peperangan antara Ali bin Abi Talib dan Mu'awiyah bin Abu Sufyan (khalifah pertama Bani Umayyah), orang-orang yang dekat di sekitar Ali menyarankan Ali agar mengambil dana dari Baitul Mal sebagai hadiah bagi orang-orang yang membantunya. Tujuannya untuk mempertahankan diri Ali sendiri dan kaum muslimin. Mendengar ucapan itu, Ali sangat marah dan berkata, "Apakah kalian memerintahkan aku untuk mencari kemenangan dengan kezaliman? Demi Allah, aku tidak akan melakukannya selama matahari masih terbit dan selama masih ada bintang di langit."(Dahlan, 1999) 


\section{BMT Pada Masa Khalifah-Khalifah Sesudahnya}

Ketika Dunia Islam berada di bawah kepemimpinan Khilafah Bani Umayyah, kondisi Baitul Mal berubah. Al Maududi menyebutkan, jika pada masa sebelumnya Baitul Mal dikelola dengan penuh kehati-hatian sebagai amanat Allah SWT dan amanat rakyat, maka pada masa pemerintahan Bani Umayyah Baitul Mal berada sepenuhnya di bawah kekuasaan Khalifah tanpa dapat dipertanyakan atau dikritik oleh rakyat (Dahlan, 1999).

Keadaan di atas berlangsung sampai datangnya Khalifah ke-8 Bani Umayyah, yakni Umar bin Abdul Aziz (memerintah 717-720 M). Umar berupaya untuk membersihkan Baitul Mal dari pemasukan harta yang tidak halal dan berusaha mendistribusikannya kepada yang berhak menerimanya. Umar membuat perhitungan dengan para Amir bawahannya agar mereka mengembalikan harta yang sebelumnya bersumber dari sesuatu yang tidak sah. Di samping itu, Umar sendiri mengembalikan milik pribadinya sendiri, yang waktu itu berjumlah sekitar 40.000 dinar setahun, ke Baitul Mal. Harta tersebut diperoleh dan warisan ayahnya, Abdul Aziz bin Marwan. Di antara harta itu terdapat perkampungan Fadak, desa di sebelah utara Mekah, yang sejak Nabi SAW wafat dijadikan rnilik negara. Namun, Marwan bin Hakam (khalifah ke-4 Bani Umayah, memerintah 684-685 M) telah memasukkan harta tersebut sebagai milik pribadinya dan mewariskannya kepada anak-anaknya. (Dahlan, 1999)

Akan tetapi, kondisi Baitul Mal yang telah dikembalikan oleh Umar bin Abdul Aziz kepada posisi yang sebenarnya itu tidak dapat bertahan lama. Keserakahan para penguasa telah meruntuhkan sendi-sendi Baitul Mal, dan keadaan demikian berkepanjangan sampai masa Kekhilafahan Bani
Abbasiyah. Dalam keadaan demikian, tidak sedikit kritik yang datang dan ulama, namun semuanya diabaikan, atau ulama itu sendiri yang diintimidasi agar tutup mulut. Imam Abu Hanifah, pendiri Madzhab Hanafi, mengecam tindakan Abu Ja'far Al Mansur (khalifah ke-2 Bani Abbasiyah, memerintah 754-775 M), yang dipandangnya berbuat zalim dalam pemerintahannya dan berlaku curang dalam pengelolaan Baitul Mal dengan memberikan hadiah kepada banyak orang yang dekat dengannya.

Bahkan menurut sebuah kisah, lmam Abu Hanifah pernah menolak bingkisan dari Khalifah Al Mansur. Tentang sikapnya itu Imam Abu Hanifah menjelaskan: "Amirul Mukminin tidak memberiku dari hartanya sendiri. Ia memberiku dari Baitul Mal, milik kaum muslimin, sedangkan aku tidak memiliki hak darinya. Oleh sebab itu, aku menolaknya. Sekiranya Ia memberiku dari hartanya sendiri, niscaya aku akan menerimanya."

Namun bagaimana pun, terlepas dari berbagai penyimpangan yang terjadi, Baitul Mal harus diakui telah memiliki peranan penting dalam sejarah Islam sebagai lembaga negara yang banyak berjasa bagi perkembangan peradaban Islam dan penciptaan kesejahteraan bagi kaum muslimin. Keberadaannya telah menghiasi lembaran sejarah Islam dan terus berlangsung hingga runtuhnya Khilafah yang terakhir, yaitu Khilafah Utsmaniyah di Turki tahun 1924.

\section{Diwan-Diwan Baitul Mal Yang Paling Awal Terbentuk}

Pembentukan diwan-diwan (kantor-kantor) Baitul Mal yang pertama kali, yang telah dikhususkan sebagai tempat untuk menyimpan arsiparsipnya, terjadi pada masa kekhilafahan Umar bin Al Khaththab, yaitu pada tahun 20 Hijriyah. Pada masa Rasulullah SAW, 
Baitul Mal belum memiliki Diwan-Diwan tertentu, walaupun beliau telah mengangkat para penulis (kaatib) yang bertugas mencatat harta. Pada saat tersebut, beliau telah mengangkat Muaiqib bin Abi Fatimah Ad Dausiy sebagai penulis harta ghanimah, $\mathrm{Az}$ Zubair bin Al Awwam sebagai penulis harta zakat, Hudzaifah bin Al Yaman sebagai penulis taksiran panen hasil pertanian Hijaz, Abdullah bin Ruwahah sebagai penulis taksiran panen hasil pertanian Khaibar, Al Mughirah bin Syu'bah sebagai penulis hutang piutang dan mua'malat yang dilakukan negara, serta Abdullah bin Arqam sebagai penulis urusan masyarakat yang berkenaan dengan kepentingan kabilah-kabilah mereka dan kondisi sumber-sumber air mereka (Zallum, 1983)

Namun demikian pada saat itu belum ada Diwan-Diwan Baitul Mal, baik dalam arti arsip maupun kantor/tempat tertentu yang dikhususkan untuk penyimpanan arsip maupun ruangan bagi para penulis. Keadaan seperti ini juga terjadi pada masa kekhilafahan Abu Bakar.

Pada saat Umar bin Al Khaththab menjadi Khalifah dan sejalan dengan semakin gencarnya penaklukkanpenaklukkan (futuhat) yang menghasilkan banyak harta, dirasakanlah tuntutan untuk membentuk Diwan-Diwan Baitul Mal, menulis arsiparsipnya, dan membangun tempattempat khusus untuk menulis dan menyimpan arsip-arsip tersebut (Zallum, 1983).

Penyebab yang utama untuk membentuk Diwan-Diwan Baitul Mal adalah peristiwa saat $\mathrm{Abu}$ Hurairah menyerahkan harta yang melimpah ruah kepada Khalifah Umar bin Khaththab yang diperolehnya dari Bahrain (tahun 20 H/641 M)). Pada saat itu Umar bertanya kepadanya, "Apa yang kamu bawa ini?" Abu Hurairah menjawab, "Saya membawa 500 ribu dirham" Umar kaget dan berkata lagi kepadanya, "Apakah kamu sadar apa yang engkau katakan tadi? Mungkin kamu sedang ngantuk, pergi tidurlah hingga subuh." Ketika keesokan harinya Abu Hurairah kembali kepada Umar maka beliau berkata kepadanya, "Berapa banyak uang yang engkau bawa?" Abu Hurairah menjawab, "Sebanyak 500 ribu dirham" Umar berkata,"Apakah itu harta yang sah?" Abu Hurairah menjawab, "Saya tidak tahu kecuali memang demikian adanya." Kemudian Umar naik mimbar, memuji Allah dan menyanjung-Nya, kemudian berkata, "Wahai manusia, sungguh telah datang kepada kita harta yang banyak, jika kalian menghendaki, kami akan menimbangnya bagi kalian. Jika kalian menghendaki, kami akan menghitungnya." Seorang laki-laki berkata, "Wahai Amirul Mu'minin, buatlah Diwan-Diwan Baitul Mal untuk kaum muslimin, sehingga mereka dapat mengambil bagiannya dari sana."

Umar bin Khaththab lalu bermusyawarah dengan kaum muslimin mengenai pembentukan Diwan-Diwan Baitul Mal tersebut. Di antaranya hadir Ali bin Abi Thalib, Utsman bin Affan, dan Al Warid bin Hisyam bin Al Mughiroh. Pada saat itu, Ali ra. berkata kepada Umar: "Bagikanlah harta yang terkumpul kepadamu setiap tahun dan janganlah engkau tahan dari harta itu sedikitpun" Utsman berkata, "Aku melihat harta yang banyak yang mendatangi manusia. Jika mereka tidak diatur sampai diketahui mana orang yang sudah mengambil bagiannya dan mana yang belum, maka aku khawatir hal ini akan mengacaukan keadaan."

Al Warid bin Hisyam bin Al Mughirah berkata, "Ketika aku di Syam aku melihat raja-rajanya membuat Diwan-Diwan dan membangun angkatan perangnya." Mendengar keterangan tersebut, maka Khalifah Umar menyetujuinya. Kemudian ia memanggil beberapa orang keturunan Quraisy, yaitu 
'Uqail bin Abi Thalib, Mukharamah bin Naufal, dan Jabir bin Muth'im. Umar lalu berkata kepada mereka, "Tulislah oleh kalian nama-nama semua rakyat berdasarkan kabilah-kabilahnya." Mereka melaksanakan perintah tersebut dengan memulai penulisan dari Bani Hasyim, kemudian Abu Bakar dan kaumnya, Umar dan kaumnya, serta diikuti dengan kabilah-kabilah lainnya. Kemudian mereka menyerahkannya kepada Umar dan ketika Umar melihat hal tersebut beliau berkata: "Tidak, bukan seperti ini yang aku maksud, tapi mulailah dari kerabat Rasulullah SAW, yaitu yang paling dekat kepada beliau, maka tulislah kedudukannya itu sehingga kalian dapat menempatkan Umar sebagaimana Allah SWT telah menetapkannya." (Zallum, 1983)

\section{Diwan-Diwan Baitul Mal Yang Ada Kemudian}

Yang diuraikan sebelumnya adalah Diwan (dalam arti arsip) yang pertama kali ada, yaitu Diwan untuk pemberian harta dan angkatan bersenjata (Diwan Al 'Atha' wal Jund). Seluruhnya ditulis dalam bahasa Arab. Adapun Diwan untuk pemasukan dan pemungutan harta (Diwan Al Istifa' wa Jibayatul Amwal), tidak ditulis dalam bahasa Arab, tetapi ditulis dalam bahasa wilayah masing-masing, misalnya Diwan Irak ditulis dalam Bahasa Persia, sebagaimana yang terjadi pada masa Persia sebelumnya. Demikian juga negeri-negeri lain yang dulunya tunduk kepada kekuasaan Persia, Diwan yang mencatat pemasukan kharaj, jizyah, dan pemungutan hartanya ditulis dalam bahasa Persia. Adapun untuk negeri Syam dan daerah-daerah yang dulunya tunduk kepada kekuasaan Romawi, maka Diwannya ditulis dalam bahasa Romawi.

Keadaan tersebut, baik untuk Irak maupun Syam, terus berlangsung demikian dari masa Kekhilafahan Umar bin Khaththab sampai masa Khalifah Abdul Malik bin Marwan dari Bani Umayyah. Pada tahun $81 \mathrm{H}$, Diwan yang mencatat segala sesuatu mengenai urusan harta negeri Syam, diubah penulisannya dengan bahasa Arab.

Yang mendorong Abdul Malik bin Marwan melakukan perubahan penulisan tersebut, adalah suatu peristiwa di mana seorang penulis Diwan itu, yang berbangsa Romawi, suatu ketika membutuhkan tinta untuk mengisi penanya. Namun rupanya ia tidak mendapatkannya. Lalu sebagai gantinya ia gunakan air kencingnya sebagai tinta untuk penanya. Kejadian lalu ini dilaporkan kepada Khalifah Abdul Malik bin Marwan. Beliau lalu menindaknya dan memerintahkan Sulaiman bin Sa'ad untuk mengubah Diwan tersebut dengan bahasa Arab.

Adapun Diwan yang mencatat segala urusan harta negeri Irak, dalam hal ini Al-Hajjaj, Wali yang diangkat Abdul Malik bin Marwan di Irak, telah memerintahkan penulisnya yang bernama Shalih bin Aburrahman untuk mengubah Diwan dari bahasa Persia menjadi bahasa Arab. Ketika hal tersebut diketahui oleh salah seorang penulis Al Hajjaj yang berkebangsaan Persia, bernama Muradansyah bin Zadaan Farukh, dia berusaha menyuap Shalih 100 ribu dirham agar Shalih tidak melakukan tugas itu, namun Shalih menolaknya (Zallum, 1983).

Dari uraian diatas nampak bahwa sejarah menjelaskan Baitul Mal dimasa khalifah Rasyidin terutama pada khalifah Umar bin Khatab sangat membantu meningkatkan kesejahteraan umat muslim dan mempunyai fungsi yang lebih luas, berbeda dengan Baitul Mal wa Tamwil pada masa sekarang.

\section{Sumber Dana Atau Harta Baitul Mal}

Syaikh Taqiyyuddin An Nabhani dalam kitabnya An Nizham Al Iqtishadi fi 
Al Islam (1990) telah menjelaskan sumber-sumber pemasukan bagi Baitul Mal dan kaidah-kaidah pengelolaan hartanya. Sumber-sumber tetap bagi Baitul Mal menurutnya adalah: fai', ghanimah/anfal, kharaj, jizyah, pemasukan dari harta milik umum, pemasukan dari harta milik negara, usyuur, khumus dari rikaz, tambang, serta harta zakat (An Nabhani, 1990).

Hanya saja, harta zakat diletakkan pada kas khusus Baitul Mal, dan tidak diberikan selain untuk delapan ashnaf (kelompok) yang telah disebutkan di dalam Al Qur'an. Tidak sedikit pun dari harta zakat tersebut boleh diberikan kepada selain delapan ashnaf tersebut, baik untuk urusan negara, maupun urusan umat.

Imam (Khalifah) boleh saja memberikan harta zakat tersebut berdasarkan pendapat dan ijtihadnya kepada siapa saja dari kalangan delapan ashnaf tersebut. Imam (Khalifah) juga berhak untuk memberikan harta tersebut kepada satu ashnaf atau lebih, atau membagikannya kepada mereka semuanya (An Nabhani, 1990).

Begitu pula pemasukan harta dari hak milik umum. Harta itu diletakkan pada Diwan khusus Baitul Mal, dan tidak boleh dicampuradukkan dengan yang lain. Sebab harta tersebut menjadi hak milik seluruh kaum muslimin, yang diberikan oleh Khalifah sesuai dengan kemaslahatan kaum muslimin yang menjadi pandangan dan ijtihadnya berdasarkan hukum-hukum syara'.

Sedangkan harta-harta yang lain, yang merupakan hak Baitul Mal, diletakkan secara bercampur pada Baitul Mal dengan harta yang lain, serta dibelanjakan untuk urusan negara dan urusan umat, juga delapan ashnaf, dan apa saja yang penting menurut pandangan negara.

Apabila harta-harta ini cukup untuk memenuhi kebutuhan-kebutuhan rakyat, maka cukuplah dengan harta tersebut. Apabila tidak, maka negara berhak mewajibkan pajak (dharibah) kepada seluruh kaum muslimin, untuk menunaikan tuntutan dari pelayanan urusan umat (An Nabhani, 1990).

Yang juga termasuk dalam kategori sumber pemasukan yang diletakkan di dalam Baitul Mal dan dibelanjakan untuk kepentingan rakyat, adalah harta yang diperoleh oleh seorang 'asyir dari kafir harbi dan mu'ahad (disebut dengan istilah usyuur), harta-harta yang diperoleh dari hak milik umum atau hak milik negara, dan harta-harta waris dari orang yang tidak mempunyai ahli waris (An Nabhani, 1990).

Apabila hak-hak Baitul Mal tersebut lebih untuk membayar tanggungannya, misalnya harta yang ada melebihi belanja yang dituntut dari Baitul Mal, maka harus diteliti terlebih dahulu : Apabila kelebihan tersebut berasal dari harta fai', maka kelebihan tersebut diberikan kepada rakyat dalam bentuk pemberian. Apabila kelebihan tersebut berasal dari harta jizyah dan kharaj, Baitul Mal akan menahan harta tersebut untuk disalurkan pada kejadian-kejadian yang menimpa kaum muslimin, dan Baitul Mal tidak akan membebaskan jizyah dan kharaj tersebut dari orang yang wajib membayarnya. Sebab, hukum syara' mewajibkan jizyah dari orang yang mampu, dan mewajibkan kharaj dari tanah berdasarkan kadar kandungan tanahnya. Apabila kelebihan tersebut dari zakat, maka kelebihan tersebut harus disimpan di dalam Baitul Mal hingga ditemukan delapan ashnaf yang mendapatkan Diwan harta tersebut. Maka, ketika ditemukan kelebihan tersebut akan dibagikan kepada yang bersangkutan. Apabila kelebihan tersebut berasal dari harta yang diwajibkan kepada kaum muslimin, maka kewajiban tersebut dihentikan 
dari mereka, dan mereka dibebaskan dari pembayaran tersebut (An Nabhani, 1990).

\section{Baitul Mal wa Tamwil Pada Masa Sekarang}

Pada sekarang ini baitul mal wa tamwil didirikan dari sekelompok swadaya masyarakat yang mempunyai tujuan yang sama dan untuk memenuhi kebutuhan yang sama, karena tujuan yang sama ini dan ingin mendapat ridho dari Allah maka dijalankan dengan prinsip yang syariah.

Prinsip kerja sama merupakan prinsip universal yang selalu ada dalam leteratur ekonomi Islam, manusia sebagai makhluk yang mendapat mandat dari Khaliqnya untuk mewujudkan perdamaian dan kemakmuran di muka bumi mempunyai dua wajah yang tidak dapat dipisahkan satu sama lainnya, yaitu sebagai makhluk individu dan sebagai makhluk sosial. (Hasan Ali, 2004 : 128)

BMT pada masa sekarang ini memiliki fungsi sebagai penerima simpanan. Pada dasarnya, penerima simpanan adalah yad al-amanah (tangan amanah), artinya ia tidak bertanggung jawab atas kehilangan atau kerusakan pada aset titipan selama hal ini bukan akibat dari kelalaian atau kecerobohan yang memelihara barang titipan (karena faktor-faktor diluar batas kemampuan).

Akan tetapi,dalam aktifitas perekonomian modern, penerima simpanan tidak mungkin akan mengidle-kan aset tersebut, akan tetapi mempergunakannya dalam aktivitas perekonomian tertentu. Karena itu pihak BMT dalam hal ini meminta izin kepada nasabah untuk kemudian mempergunakan simpanan tersebut dengan catatan menjamin akan mengembalikan aset tersebut secara utuh. Dengan demikian BMT bukan lagi yad amanah akan tetapi yad adh- dhamanah (tangan penanggung) yang bertanggung jawab atas segala kehilangan dan kerusakan yang terjadi.

Selain itu, BMT akan memberikan hadiah kepada nasabah, dengan syaratsyarat tertentu. Seiring dengan jalannya perekenomian dalam kehidupan seharihari, pihak yang menjalankan usaha perekonomian tentunya memiliki keuntungan, meskipun kadangkala mengalami kerugian. BMT yang juga bergerak dalam bidang perbisnisan juga tentunya akan memiliki keuntungan dan mungkin saja akan mendapatkan keuntungan yang besar. Karena itu BMT tidak akan menyia-nyiakan nasabah. Pihak BMT akan memberikan Hadiah atau Bonus kepada Nasabah, demi menjaga hubungan baik antara nasabah dan BMT dan menimbulkan rasa kecintaan antara sesama. Jenis hadiah ditentukan oleh pihak $B M T$, dan pihak $B M T$ akan memberikan hadiah yang lebih besar sesuai besar saldo nasabah.

Disamping itu BMT juga berperan dalam memberikan pinjaman. Dalam kehidupan sehari-hari manusia tidak terlepas dari kekurangan dan kesusahan. Dalam Hal ini pihak BMT menjadi solusi bagi Anggota maupun yang lainnya. BMT dapat meminjamkan uang kepada yang membutuhkan dengan syarat-syarat tertentu. Misalnya, pinjaman hanya akan diberikan untuk hal-hal yang baik dan tidak bertentangan dengan syari'ah. Oleh karena itu pihak BMT harus mengetahui tujuan peminjaman.

$B M T$ dapat pula dikategorikan dengan koperasi syariah yakni lembaga ekonomi yang berfungsi untuk menarik, mengelola dan menyalurkan dana dari, oleh dan untuk masyarakat, jika demikian berarti $B M T$ dapat disebut sebagai lembaga swadaya ekonomi umat yang dibentuk dari, oleh dan untuk masyarakat. Selain itu merupakan lembaga pengelola dana masyarakat yang memberikan pelayanan tabungan, 
pinjaman kredit dan pembiayaan, $B M T$ juga dapat berfungsi mengelola dana sosial umat diantaranya menerima titipan dana zakat, infaq, shadaqah dan wakaf. Semua produk pelayanan dan jasa BMT dilakukan menurut ketentuan syariah yakni prinsip bagi hasil (profit and loss sharing).

Tabel 1: Perbedaan Baitul Mal Masa Dulu Dan BMT Masa Sekarang

\section{Baitul Mal Masa Dulu}

1. Merupakan Lembaga Khusus Negara

2. Pendiri awalnya Waliyyul Amri

(Rasulullah saw), pendirian secara formal Khulafaur Rasyidin

3. Bersifat menyimpan dan mengolah segala macam harta yang menjadi pendapatan negara

4. Sumber harta ghanimah (harta rampasan perang badar), tanah, bangunan, barang tambang, uang, komuditas perdagangan dan harta benda lainnya

5. Sebagai hak bagi seluruh kaum muslimin

6. Harta yang didapat langsung dibagikan pada kaum muslimin

7. Pada masa Abu bakar sebagai penyimpan harta negara

8. Pada masa Umar bin Khathab menjadi penyimpanan harta negara yang dikelola dengan mendirikan kantor atau diwan-diwan yang ada pegawainya sebagai pengelolah

9. Pada masa Umar bin Abdul Aziz lebih dikembang secara, rapi, bersih dan teratur artinya harta yang ada sesuai dengan syariah dan ditribusikan kepada seluruh kaum muslimin dan ada yang seperlima untuk disimpan sebagai keperluan bila terjadi keadaan yang darurat

10. Berfungsi seperti Departemen Keuangan pada masa sekarang

\section{BMT Masa Sekarang}

1. Merupakan Balai Usaha Mandiri

2. Pendirinya Kelompok Swadaya Masyarakat

3. Bersifat bisnis yang utama dan sosial sebagai penunjang

4. Sebagai pengembang usaha Produktif dan Investasi

5. Sasaran yang utama untuk pengembangan usaha kecil dan mikro

6. Harta bersumber titipan Zakat, Infak dan Shadaqah

7. Harta diberdayakan dulu atau Mendayagunakan untuk mendapatkan Penghasilan yang sesuai dengan syariah

8. Sebagai pengawas dan Pengembangnya adalah PINBUK (Pusat Inkubasi BisnisUsaha Kecil)

9. Sebagai landasan beroperasi adalah UU No: 7/1992 dan UU No: 10/1998 Dan PP No: 72 / 1992 tentang Prinsip Bagi Hasil

10. Berfungsi untuk mengentaskan kemiskinan dan sebagai kekuatan ekonomi keumatan (kerakyatan)

\section{Kinerja Keuangan BMT}

Berdasarkan keputusan Menteri Keungan Republik Indonesia Nomor 401KMK.00/1989 tanggal 28 Juni 1989, yang dimaksud dengan kinerja keuangan adalah prestasi yang dicapai oleh perusahaan dalam periode tertentu yang mencerminkan kesehatan dari perusahaan tersebut (Jamal lulail Yunus, 2009: 38)

Kinerja keuangan perusahaan merupakan salah satu dasar penilain mengenai kondisi keuangan perusahaan yang dapat dikaukan berdsarkan analisis terhadap rasio-rasio keuangan (Jamal lulail Yunus, 2009: 38). Dalam hal ini Husnan mengatakan bahwa untuk 
melakukan penilaian terhadap prestasi dan kondidsisi keuangan perushaan, seorang analis keuangan memerlukan ukuran-ukuran tertentu. (Jamal lulail Yunus, 2009: 39)

Berdasarkan pendapat-pendapat diatas dapat disimpukan bahwa untuk melakukan analisis terhadap keuangan suatu perusahaan dibutuhkan suatu tolak ukur yang dapat menggambarkan bagaimana kondisi dan prestasi yang dicapai oleh perusahaan tersebut dengan cara melakukan antara satu perusahaan dengan perusahaan lain yang sejenis atau dengan rata-rata industrinya (Jamal lulail Yunus, 2009: 39)

Analisis rasio merupakan salah satu alat analisis keuangan yang paling populer dan banyak digunakan (Hery, 2012: 22)

Menurut James C. Van Horne, rasio keuangan merupakan indeks yang menghubungkan dua angka akuntansi dan diperoleh dengan membagi satu angka dengan angka lainnya. Rasio keuangan ini digunakan untuk mengevaluasi kondisi kedisi keuangan dan kinerja keuangan. Dari hasil rasio keuangan ini akan kelihatan kondisi kesehatan lembaga yang bersangkutan. (Kasmir, 2010; 92)

Return on Investmen (ROI) adalah merupakan pengukuran kemampuan perushaan secara keseluruhan dalam menghasilkan keuntungandengan jumlah keseluruhan aktiva yang tersedia dalam perusahaan. Semkin tinggi rasio ini semakin baik keadaan suatu perusahaan (Lukman Syamsudin,1998: 63)

\section{METODE}

Penelitian ini termasuk penelitian deskriptif analitik yaitu dengan mendeskripsikan objek yang akan diteliti berdasarkan fakta atau data yang tampak atau sebagaimana adanya.
Sehingga penelitian ini banyak melakukan pengambilan data dari lapangan yang langsung ke objek penelitian, untuk diperbandingkan dengan teori-teori yang ada. Untuk BMT Al-Ittihad Pekanbaru data diperoleh dengan cara langsung mengunjungi BMT tersebut, kemudian melakukan wawancara dengan staf BMT atau pegawai bagian akunting, selesai itu melakukan pengumpulan data yang bersifat dokumen seperti laporan keuangan BMT, sampai pada sejarah $B M T$ berdiri dan dokumen yang lain, yang mendukung penelitian untuk dijadikan sebagai suatu dokumentasi, supaya mempermudah dalam menganalisa kinerja keuangan $B M T$ tersebut.

Dari kegiatan pengumpulan data yang diambil langsung dari lapangan yaitu kelokasi BMT Al-Ittihad Pekanbaru, maka data tersebut menjadi hasil dari penelitian lapangan yang biasa disebut sebagai field research atau qualitatif research. Data lapangan dan teori yang ada lalu disatukan dengan menganalisa apa yang cocok untuk penggunaan teori yang didapat dari data pustaka atau buku-buku yang mendukung dalam penelitian ini.

Penelitian ini di laksanakan di BMT Al-Ittihad yang berada di jalan Damar 610 Camp PT. Chevron Rumbai Pekanbaru. Adapun laporan keuangan yang terjadi pada BMT Al-Ittihad Pekanbaru pada tahun 2011 sampai dengan tahun 2014.

Adapun data yang penulis gunakan dalam penelitian ini adalah sebagai berikut : (1) Data primer yaitu data yang diperoleh dari hasil wawancara dengan pegawai atau Badan pengelola BMT Al-Ittihad Pekanbaru dalam pelaksanaan meraih pendapatan dan mendapat keuntungan dari Sisa Hasil Usaha setiap periode; dan (2) Data sekunder yaitu data yang diperoleh langsung dari pihak perusahaan, dalam 
hal ini bagian keuangan atau akuntingnya dalam $B M T$, berupa laporan keuangan perusahaan yaitu neraca dan laba rugi. Sedangkan data lainnya berupa sejarah bedirinya perusahaan $B M T$ dan srtuktur organisasi BMT.

Metode pengumpulan data dalam penelitian ini adalah: (1) Dokumentasi; (2) wawancara; (3) Observasi; dan (4)Kepustakaan.

Sedangkan dalam menganalisa data yang ada, penulis menggunakan metode pendekatan deskriptif yaitu dengan cara mengumpulkan data kemudian ditabulasikan kedalam tabel dan selanjutnya diuraikan secara sistematis, dan dihubungkan dengan teori-teori yang relevan sehingga dapat dilakukan pendekatan terhadap pemecahan masalah. Adapun alat analisis yang digunakan adalah analisis rasio keuangan yaitu ratio likuiditas, ratio aktivitas, dan ratio profitabilitas.

Adapun hipotesis pada penelitian ini dirumuskan sebagai berikut: "Kinerja keuangan yang terjadi pada pendapatan BMT Al-Ittihad Pekanbaru belum berjalan secara efektif dan efesien."

\section{HASIL DAN PEMBAHASAN

Gambaran Umum BMT Al-Ittihad
Pekanbaru

BMT Al-Ittihad Pekanbaru salah satu $B M T$ yang ada di kota Pekanbaru tepatnya di jalan Damar 610 Camp PT. Chevron Rumbai Pekanbaru. BMT ini memiliki kantor cabang antara lain cabang Rumbai jalan Khayangan No. 46 Pekanbaru, kantor cabang Panam jalan Delima No. 138 kelurahan Delima kecamatan Tampan Pekanbaru, kantor cabang Duri jalan Mawar No. 17 kelurahan Balik Alam kecamatan Mandau Duri kabupaten Bengkalis, kantor kas Duri Bank Center PT. Chevron Pasific Indonesia IndonesiaDuri. BMT ini merupakan lembaga keuangan syariah yang banyak melayani masyarakat, khususnya anggotanya dan karyawan PT. Chevron yang ada di Pekanbaru dan Duri maupun masyarakat umum yang menggunakan jasa BMT tersebut. Hal ini sangat membantu para pedagang kecil, para petani dan pengusaha kerajinan baik dalam pembuatan mebel, yang sebagian mendapat pembiayaan dari $B M T$ tersebut.

Maka untuk menanggulangi hal tersebut, pada tahun 2000 Koperasi Syariah Baitul Maal wat Tamwil (BMT) didirikan yang merupakan suatu Badan Usaha Milik karyawan PT.Chevron di Pekanbaru dan telah diresmikan pada pada tanggal 15 Juni tahun 2000, dengan nama Koperasi Syariah BMT Al-Ittihad, yang bertujuan: (1) Meningkatkan kesejahteraan anggota pada khususnya dan masyarakat pada umumnya serta ikut membangun tatanan perekonomian nasional dalam rangka menggalang terwujudnya masyarakat yang maju, adil dan makmur; (2) Berperan sebagai Kelompok Swadaya Masyarakat Baitul Maal wat Tamwil yang menciptakan sumber pembiayaan dan penyediaan modal bagi anggotanya dengan sistem bagi hasil yang pantas dan layak; (3) Mengembangkan sikap menghemat penggunaan uang secara berencana dan bijaksana oleh para anggotanya; dan (4) Mendorong dan menumbuhkan usahausaha produktif guna meningkatkan pendapatan serta berdampak multiplier effect positif.

\section{Struktur Organisasi BMT}

Sebagaimana halnya sebuah organisasi maka Baitul Maal wat Tamwil memiliki struktur organisasi yang fungsinya adalah mengatur bagaimana pembagian wewenang serta tanggung jawab masing-masing seperti ketua atau manager atau direktur, pengurus dan para karyawan atau pegawai BMT sehingga dengan demikian 
komponen yang ada pada BMT tersebut dapat berjalan dengan lancar. Struktur organisasi BMT yang paling sederhana harus terdiri dari Badan Pendiri, Badan Pengawas, Anggota BMT dan Badan Pengelola.

Adapun tugas dan kewajiban itu telah ditetapan pada saat seseorang itu diangkat menjadi pengurus BMT antara lain: (a) Direktur, Manager atau Ketua adalah sebagai pimpinan tertinggi dalam pelaksanaan dan tanggung jawab penuh atas setiap tindakan baik dalam funding maupun landing dana; (b) Akunting adalah bertanggung jawab dalam aktifitas administrasi dan pembukuan serta membuat laporan bulanan maupun tahunan serta keamanan harta milik BMT; (c) Marketing adalah suatu kegiatan pemasaran yang bertanggung jawab untuk mencari nasabah serta mengutip dana angsuran bulanan nasabah agar kredit macet dapat diminimalisasi serta aktifitas hubungan keluar; dan (d) Kasir sebagai pelaksana dan penanggung jawab dari aktifitas masuk dan keluarnya uang kas, membuat laporan harian, pembukuan mutasi simpanan anggota penabung dan peminjam.

\section{Analisis Kinerja Keuangan BMT}

Untuk memudahkan dalam penelitian analisa kinerja keuangan, dibagi dalam beberapa pendekatan yang dapat mengantarkan keanalisa yang lebih akurat dalam pengelolaan data, adapun pendekatan yang dilakukan sebagai berikut :

\section{Penerimaan (Revenue)}

Penerimaan atau pendapatan bagi sebuah $B M T$ sangat penting bagi kelangsungan hidup $B M T$ tersebut, pendapatan yang diterima oleh BMT AlIttihad Pekanbaru, terdiri dari pendapatan jasa dan pendapatan lainlain, ini dikarenakan diunit yang lain sementara dihentikan karena mengalami kerugian, sehingga yang berjalan saat ini hanya unit pendanaan baik dari pembiayaan maupun penghimpunan dana. Untuk mengetahui bagaimana perkembangan pendapatan BMT Al-Ittihad Pekanbaru selama empat tahun terakhir dapat dilihat seperti pada tabel berikut.

Tabel 2. Perkembangan Penerimaan BMT Al-Ittihad Pekanbaru Periode Tahun 2011-2014

\begin{tabular}{|c|c|c|c|c|}
\hline \multirow[t]{2}{*}{ Tahun } & \multicolumn{2}{|c|}{ Sumber Pendapatan } & \multirow[t]{2}{*}{ Total Pendapatan } & \multirow{2}{*}{$\begin{array}{c}\% \\
\text { Perkembangan } \\
\end{array}$} \\
\hline & Pendapatan Jasa & Pendapatan lain & & \\
\hline 2011 & 3.361 .426 .147 & 1.375 .716 & 3.362 .801 .863 & 0 \\
\hline 2012 & 4.020 .858 .352 & 1.202 .114 & 4.022 .060 .466 & $19 \%$ \\
\hline 2013 & 4.534 .027 .324 & 1.333 .836 & 4.535 .361 .160 & $15 \%$ \\
\hline 2014 & 5.574 .820 .041 & 1.420 .697 & 5.576 .240 .738 & $0,30 \%$ \\
\hline
\end{tabular}

Sumber : Laporan Keuangan BMT Al-Ittihad Pekanbaru

Selama empat tahun terakhir pendapatan mengalami peningkatan dengan presentase terlihat dalam tabel 2, walaupun peningkatan itu tidak terlalu tinggi tetapi masih bisa dikatakan ada perkembangan pada usaha BMT tersebut.

Pendapatan jasa selama empat tahun terakhir mengalami peningkatan,

terdiri dari pendapatan bagi hasil, pendaptan administrasi, pendapatan jasa Bank dan pendapatan lain-lain. Bila kita analisis maka pendapatan tertinggi diperoleh pada tahun 2014 ini dikarenakan pendapatan jasa meningkat diikuti pendapatan lain-lain, sehingga terjadi kenaikan tentunya diikuti dengan pelayanan yang baik. 


\section{Pengeluaran atau Biaya (Cost)}

Hal lain yang perlu diperhatikan dalam pengelolaan keuangan sebuah $B M T$ adalah mengenai biaya, biaya-biaya yang biasanya terjadi dalam sebuah $B M T$ adalah biaya usaha, biaya administrasi dan umum serta biaya lain-lain yang tak terduga. Biaya-biaya tersebut dikeluarkan untuk membiayai kegiatan operasional BMT seperti kegiatan usaha, membeli alat tulis, membeli keperluan kantor lainnya dan membayar gaji pengurus dan pengeluaran biaya untuk yang lainnya. Untuk mengetahui rincian biaya terlihat pada Tabel berikut.

\section{Tabel 3: Rincian Biaya Operasional BMT Al-Ittihad Pekanbaru}

\begin{tabular}{cccccc}
\hline Tahun & Biaya Usaha & $\begin{array}{c}\text { Biaya Adm \& } \\
\text { Umum }\end{array}$ & Biaya Lain & Total Biaya & Perkembangan \\
\hline 2011 & 1.841 .900 .698 & 877.513 .717 & 84.619 .741 & 2.804 .034 .156 & 0 \\
\hline 2012 & 2.588 .704 .993 & 695.598 .888 & 60.512 .629 & 3.334 .816 .510 & $0,18 \%$ \\
\hline 2013 & 2.828 .540 .528 & 815.469 .035 & 98.207 .670 & 3.742 .217 .233 & $0,14 \%$ \\
\hline 2014 & 3.459 .495 .138 & 1.016 .906 .151 & 161.452 .432 & 4.637 .853 .721 & $0,31 \%$ \\
\hline
\end{tabular}

Sumber : Laporan Keuangan BMT Al-Ittihad Pekanbaru

Berdasarkan tabel 3 terlihat bahwa jumlah biaya yang dikeluarkan oleh $B M T$ Al-Ittihad Pekanbaru setiap tahunnya selama empat tahun terakhir mengalami peningkatan hal ini disebabkan karena semakin banyak kegiatan untuk pelayanan kepada masyarakat maupun anggota BMT tersebut, kegiatan usaha, administrasi dan umum yang dilakukan oleh BMT Al-Ittihad Pekanbaru, sehingga pengeluaran biaya semakin meningkat.

Dilihat untuk biaya usaha selama empat tahun terakhir mengalami peningkatan, peningkatan penggunaan biaya ini disebabkan oleh kegiatan usaha, seperti penagihan pinjaman yang belum tertagih, biaya gaji yang menyesuaikan dengan kondisi setempat dan perawatan kenderaan yang ada untuk kegiatan BMT dalam melakukan kegiatan usaha, baik keperluan untuk penyaluran dana maupun penghimpunan dana masyarakat.

\section{Sisa Hasil Usaha (SHU)}

Keberhasilan manajemen dari sebuah BMT biasanya dapat dilihat dari perolehan $S H U$ yang merupakan laba kegiatan sebuah BMT. Sisa Hasil Usaha diperoleh dari pendapatan setelah dikurangi dengan biaya usaha, biaya administrasi dan umum dan biaya lainlain. Dengan demikian $S H U$ merupakan tolak ukur keberhasilan sebuah BMT, tetapi hal itu tidak bisa dijadikan patokan bahwa BMT itu telah berhasil dalam mengatur perputaran modal usahanya.

Untuk mengetahui lebih jelas mengenai perolehan laba bersih selama empat tahun terakhir dapat dilihat pada Tabel 4.4

Tabel. 4: Perkembangan Sisa Hasil Usaha BMT Al-Ittihad Pekanbaru

\begin{tabular}{rcccc}
\hline Tahun & Penerimaan kotor & Pengeluaran (Biaya) & SHU (Laba bersih) & Perkembangan \\
\hline 2011 & 547.391 .467 & 2.804 .034 .156 & 544.888 .967 & 0 \\
\hline 2012 & 676.041 .842 & 3.344 .816 .610 & 673.833 .842 & $0,24 \%$ \\
\hline 2013 & 791.810 .091 & 3.742 .217 .233 & 788.982 .091 & $0,21 \%$ \\
\hline 2014 & 936.966 .319 & 4.637 .853 .721 & 932.080 .319 & $0,26 \%$ \\
\hline
\end{tabular}

Sumber : Laporan Keuangan BMT Al-Ittihad Pekanbaru 
Berdasarkan tabel 4 dapat dilihat bahwa laba bersih selama empat tahun terakhir dapat mempertahankan stabilitas. Pada tahun 2011 laba bersih yang diperoleh BMT Al-Ittihad Pekanbaru relatif lebih kecil dari 2012, laba ini diperoleh dari keuntungan pendapatan jasa dan pendapatan lainlain.

Kemudian untuk tahun 2012 laba bersih mengalami peningkatan yang cukup normal, hal ini disebabkan pendapatan mengalami peningkatan tetapi dibarengi dengan peningkatan biaya, sehingga laba yang dihasilkan dapat bertahan relatif stabil dibandingkan tahun sebelumnya.

Untuk tahun 2013, SHU operasi kembali mengalami peningkatan, hal ini karena peningkatan $S H U$ kotor juga diiringi oleh peningkatan dalam pengeluaran sehingga laba bersih normal. Kita lihat untuk tahun 2014, laba bersih kembali mengalami kenaikan, walaupun biaya meningkat tetapi dibarengi dengan peningkatan penerimaan kotor yang lebih besar lagi.

\section{Analisis Rasio Keuangan BMT}

Untuk menilai kondisi keuangan dan prestasi suatu BMT, memerlukan beberapa tolak ukur, yang sering digunakan adalah rasio atau indeks yang menghubungkan dua data keuangan yang satu dengan yang lainnya.

Berdasarkan laporan keuangan BMT Al-Ittihad Pekanbaru selama empat tahun terakhir maka dapat dihitung beberapa rasio sebagai berikut :

\section{Ratio Likuiditas}

Yaitu untuk mengukur tingkat likuiditas $B M T$, yaitu kemampuan untuk membayar hutangnya dengan segera dengan aktiva lancar. Dengan mengetahui current ratio dalam laporan keuangan yang ada pada BMT Al-Ittihad Pekanbaru.

Current Ratio $=$ Aktiva lancar $\times 100$ $\%$

\section{Hutang lancar}

Untuk mengetahui nilai current ratio suatu $B M T$ maka diperlukan data data seperti pada Tabel 4.5

Tabel 5: Perkembangan Aktiva lancar, Hutang lancar dan Current Ratio BMT

\begin{tabular}{ccccc}
\hline Tahun & Aktiva lancar & Hutang lancar & Current Ratio & Perkembangan \\
\hline 2011 & 36.548 .027 .138 & 22.978 .362 .090 & $1,59 \%$ & 0 \\
\hline 2012 & 44.968 .885 .779 & 29.359 .833 .993 & $1,53 \%$ & $0,15 \%$ \\
\hline 2013 & 64.017 .718 .199 & 34.712 .555 .919 & $1,84 \%$ & $0,19 \%$ \\
\hline 2014 & 65.389 .663 .365 & 45.134 .145 .423 & $1,44 \%$ & $(0,25 \%)$ \\
\hline
\end{tabular}

Sumber : Laporan Keuangan BMT Al-Ittihad Pekanbaru

Current Ratio apa bila dilihat dari tabel 4.5 selama empat tahun yaitu 2011-2014 mengalami peningkatan, tahun 2012 mengalami penurunan, tetapi pada tahun 2013 meningkat dan tahun 2014 juga menurun.

Untuk tahun 2011 tampak pada Tabel: 4.5 , current ratio nilainya adalah 1,59 \%, hal ini karena aktiva lancar lebih besar dari kewajiban lancar, sehingga kemampuan membayar hutang dengan segera oleh aktiva lancar sebagai penjamin dalam satu rupiah hutang dijamin dengan aktiva lancar senilai Rp 1,59. Current ratio pada tahun 2012 mengalami penurunan, hal ini disebabkan dapat mempertahankan aktiva lancar untuk meningkat.

Pada tahun 2013 current ratio bernilai $1,84 \%$ mengalami peningkatan tetapi peningkatan ini tetap dapat mempertahankan peningkatan akativa lancar dari nilai pada tahun 2011. Nilai current ratio $1,84 \%$ ini berarti bahwa 
hutang yang segera harus dilunasi dijamin oleh aktiva lancar dalam satu rupiah dijamin oleh aktiva lancar $\mathrm{Rp}$ 1.84.

Untuk tahun 2014 nilai dari current ratio mengalami penurunan lagi tetapi penurunan ini tetap dapat mempertahankan peningkatan aktiva lancar, nilai 1,44\% ini mendekati satu, sehingga posisi keuangan lebih baik dari tahun-tahun sebelumnya, bila dilihat nilai ini berarti dalam satu rupiah hutang yang segera dilunasi dijamin oleh aktiva lancar Rp 1,44.

Dari perhitungan tabel 4.5 dapat diketahui bahwa BMT Al-Ittihad Pekanbaru memiliki current ratio yang

Tabel 6: Perkembangan Pendapatan, Total Aktiva Dan Total Assets Turn Over BMT

\begin{tabular}{cccc}
\hline Tahun & Pendapatan & Total Aktiva & Total Assets Turn Over \\
\hline 2011 & 3.361 .426 .147 & 36.846 .416 .263 & 0,09 Kali \\
\hline 2012 & 4.020 .858 .352 & 46.283 .831 .014 & 0,08 Kali \\
\hline 2013 & 4.534 .027 .324 & 54.261 .578 .161 & 0,08 Kali \\
\hline 2014 & 5.574 .820 .041 & 66.773 .082 .210 & 0,08 Kali \\
\hline
\end{tabular}

Sumber : Laporan keuangan BMT Al-Ittihad Pekanbaru

Berdasarkan Tabel 6 dapat diketahui bahwa dana yang tertanam dalam keselurahan aktiva rata-rata dalam tiap tahunnya berputar antara 0,08 kali sampai dengan 0,09 kali, ini berarti setiap satu rupiah aktiva dalam setiap tahunnya menghasilkan revenue antara Rp 0,08 hingga Rp 0,09.

Bila dilihat perkembangan total assets turn over tidak terjadi peningkatan setiap tahun tetapi hanya relatif normal, karena nilai perputaran uang mendekati 100 persen.

Walaupun pendapatan dilihat setiap tahunnya meningkat tetapi tidaklah mendekati total aktiva yang digunakan sebagai sumber dana untuk pengelolaannya, dengan demikian dapat dikatakan tingkat efektivitasnya masih rendah. rendah, karena setiap $\mathrm{Rp} 1$ hutang lancar rata-rata dijamin oleh aktiva lancar Rp 1,44 hingga Rp 1,84.

\section{Ratio Aktivitas}

Yaitu untuk mengukur sampai berapa besar efektivitas BMT Al-Ittihad Pekanbaru dalam mengelola sumber dananya.

Total Assets Turn Over = $\underline{\text { Pendapatan }}$ X 1

Total Aktiva

Dilihat perkembangan total assets turn over BMT Al-Ittihad Pekanbaru selama empat tahun terakhir seperti terlihat pada tabel berikut. 
Dilihat keadaan ratio profit dari tahun 2011 sampai dengan tahun margin pada BMT Al-Ittihad Pekanbaru

Tabel 7: Perkembangan Profit Margin BMT Al-Ittihad Pekanbaru Tahun Sisa Hasil Usaha (SHU) Pendapatan Profit Margin Perkembangan

\begin{tabular}{llllc}
\hline 2011 & 544.888 .967 & 3.361 .426 .147 & $0,16 \%$ & 0 \\
\hline 2012 & 673.833 .842 & 4.020 .858 .352 & $0,16 \%$ & 0 \\
\hline 2013 & 788.982 .091 & 4.534 .027 .324 & $0,17 \%$ & $0,06 \%$ \\
\hline 2014 & 932.080 .319 & 5.574 .820 .041 & $0,16 \%$ & $0,06 \%$
\end{tabular}

Sumber : Laporan keuangan BMT Al-Ittihad Pekanbaru

Untuk ratio profit margin terlihat bahwa perkembangannya cenderung mengalami stabil seperti terlihat pada tabel 7 untuk tahun 2011 sampai dengan 2014 tetap stabil 0,16\%, hal ini karena jumlah laba usaha dibandingkan dengan pendapatan yang mengalami peningkatan setiap tahun. Kemudian untuk tahun 2013 terlihat bahwa ratio profit margin mengalami peningkatan sebesar $0.1 \%$, hal ini disebabkan oleh peningkatan laba usaha, sehingga terlihat pada tabel bahwa pendapatan juga ikut meningkat.

Kemudian untuk tahun 2014 kembali mengalami penurunan sebesar $0.1 \%$, hal ini disebabkan oleh peningkatan pendapatan tetapi diiringi dengan peningkatan biaya, laba tetap stabil. Untuk tahun 2014 penurunan ratio profit margin sebesar $0,16 \%$, hal ini disebabkan oleh laba usaha dan pendapatan terus meningkat, sehingga menjadi sesuatu yang didambakan oleh $B M T$, yang selama ini dapat meningkat seperti semula.

Dilihat pada ratio keuntungan dengan pendekatan metode net earning power ratio atau rate of return on investmen adalah :

Rate of Return On Investment (ROI) $=\frac{\text { SHU }}{\text { Total Aktiva }} \times 100 \%$

Tabel 8 : Perkembangan Net Earning Power Ratio atau Rate of Return on Investment

\begin{tabular}{ccccc}
\hline Tahun & Sisa Hasil Usaha (SHU) & Total Aktiva & ROI & Perkembangan \\
\hline 2011 & 544.888 .967 & 36.846 .416 .263 & $0,14 \%$ & 0 \\
\hline 2012 & 673.833 .842 & 46.283 .831 .014 & $0,14 \%$ & 0 \\
\hline 2013 & 788.982 .091 & 54.261 .578 .161 & $0,14 \%$ & 0 \\
\hline 2014 & 932.080 .319 & 66.773 .082 .210 & $0,13 \%$ & $(0.07 \%)$ \\
\hline
\end{tabular}

Sumber : Laporan keuangan BMT Al-Ittihad Pekanbaru

Bila dilihat tabel. 8 tampak bahwa terjadi penurunan kemampuan dari modal yang diinvestasikan dalam keseluruhan aktiva untuk menghasilkan keuntungan bersih sebesar 0,14\%, ini terjadi karena terlalu tinggi total aktiva pada tahun 2011 sedangkan pada tahun 2012 tetap meningkat, dan sisa hasil usaha juga mengalami peningkatan.

Pada tahun 2013 mengalami peningkatan kemampuan dari modal yang diinvestasikan dalam keseluruhan aktiva untuk menghasilkan keuntungan bersih sebesar $0,14 \%$, hal ini terjadi karena sisa hasil usaha meningkat, diiringi dengan total aktiva juga meningkat dari tahun sebelumnya. Untuk tahun 2014 tetap mengalami kestabilan lagi yaitu sebesar $0,13 \%$, ini terjadi karena peningkatan penggunaan aktiva, dan diiringi dengan peningkatan sisa hasil usaha. 
Untuk mengetahui lebih jauh bagaimana kinerja keuangan BMT AlIttihad Pekanbaru selama empat tahun buku yang telah berjalan dapat dilihat pada Tabel 4.9

Tabel 9 : Ratio Untuk Variabel Yang Diteliti

\begin{tabular}{clcccc}
\hline \multirow{2}{*}{ No } & Keterangan & \multicolumn{4}{c}{ Tahun } \\
\cline { 3 - 6 } & & 2011 & 2012 & 2013 & 2014 \\
\hline 01 & Current Ratio & 0 & 0,15 & 0,19 & $(0,25)$ \\
\hline 02 & Assets Turn Over & 0,09 & 0,08 & 0,08 & 0,08 \\
\hline 03 & Net Profit Margin & 0 & 0 & 0,06 & 0,06 \\
\hline 04 & Return On Investment (ROI) & 0 & 0 & 0 & $(0,07)$ \\
\hline
\end{tabular}

Sumber : Data Olahan Dari Hasil Penelitian

Dari tabel. 9 dapat dilihat bahwa rasio likuiditas atau current ratio BMT Al-Ittihad Pekanbaru selama empat tahun terakhir nilainya tidak mengalami fluktuasi yang berkisar antara $0 \%$ sampai dengan 0,19\%. Bila kita lihat rasio diatas termasuk stabil karena kemampuan BMT untuk membayar hutang yang harus dipenuhi dengan aktiva lancar adalah dalam setiap satu rupiah hutang lancar hanya dijamin oleh 0 rupiah hingga 0,19 rupiah aktiva lancar.

Sementara untuk rasio aktivitas atau assets turn over nilainya tidak mengalami fluktuasi yang berarti hanya berkisar antara 0,08 kali sampai dengan 0,09 kali perputaran aktiva rata-rata dalam setiap tahun. Hal ini termasuk perputaran yang cukup rendah, sebaiknya BMT dapat meningkatkan perputaran aktiva yang lebih tinggi lagi, sehingga sisa hasil usaha dapat diraih lebih tinggi dengan tidak melupakan asas sosial untuk kesejahteraan anggota dan masyarakat umumnya.

Untuk rasio keuntungan atau net profit margin nilainya terlihat pada tabel sangat rendah antara $0 \%$ hingga 0,6 \%. Ini menandakan bahwa setiap satu rupiah pendapatan dapat menghasilkan keuntungan bersih antara 0 rupiah sampai dengan 0,6 rupiah. Rasio keuntungan ini termasuk stabil, sehingga tidak mengganggu pada perkembangan setiap tahun, tetapi bila rasio ini dapat ditingkatkan maka rasio keuntungan lebih tinggi dan assets yang dimiliki otomatis akan bertambah dalam setiap tahun.

Sedangkan pada net earning power ratio atau rate of return on investment (ROI) terlihat nilainya cukup rendah antara $0 \%$ sampai dengan $(0,07 \%)$. Hal ini berarti kemampuan dari modal yang diinvestasikan dalam keseluruhan aktiva untuk menghasilkan keuntungan bersih masih rendah dan perlu ditingkatkan sehingga akan tampak bahwa kemampuan dalam mengelola dana yang diinvestasikan dapat menghasilkan keuntungan yang tinggi, dengan sendirinya masyarakat akan lebih percaya menanamkan uangnya.

Setelah dilihat Tabel. 9 maka terlihat nilai yang terdapat pada setiap analisis dari lukuiditas, rasio aktivitas dan rasio keuntungan, tampak nilai-nilai kesemua itu termasuk nilai yang rendah, bila kita lihat pada laporan keuangan yang terjadi pada BMT Al-Ittihad Pekanbaru, pendapatan yang dihasilkan tidak berfluktuasi dan biaya yang terjadi relative stabil sehingga laba yang dihasilkan dalam sisa hasil usaha menjadi normal. Dari analisis yang telah dilakukan dapat ditarik ringkasan dari temuan yang terjadi, dapat digambar secara sederhana pada tabel berikut. 
Tabel 10: Ringkasan Temuan Analisis

\begin{tabular}{|c|c|c|}
\hline Metode Perhitungan & $\begin{array}{c}\text { Temuan } \\
\end{array}$ & Interpretasi \\
\hline 1. Reveneu & $\begin{array}{l}\text { Pendapatan dari tahun 2011- } \\
2014 \text { relatif meningkat, } \\
\text { berasal dari pendapatan jasa } \\
\text { dan pendapatan lain-lain. }\end{array}$ & $\begin{array}{l}\text { Kemampuan menghasilkan } \\
\text { pendapatan baik, dan perlu } \\
\text { ditingkatkan terus. }\end{array}$ \\
\hline 2. Cost & $\begin{array}{l}\text { Pengeluaran yang terjadi } \\
\text { dari tahun 2011-2014 } \\
\text { mengalami peningkatan, } \\
\text { terutama biaya usaha. }\end{array}$ & $\begin{array}{l}\text { Kemampuan untuk menekan } \\
\text { pengeluaran dapat digolongkan } \\
\text { kurang berhasil sebaiknya } \\
\text { mengadakan perencanaan dan } \\
\text { pengawasan yang lebih ketat }\end{array}$ \\
\hline 3. SHU (Laba Bersih) & $\begin{array}{l}\text { Laba yang diperoleh dari } \\
\text { tahun 2011-2014 mengalami } \\
\text { penigkatan seperti terlihat di } \\
\text { neraca }\end{array}$ & $\begin{array}{l}\text { Kemampuan menghasilkan laba } \\
\text { yang optimal dapat digolongkan } \\
\text { berhasil }\end{array}$ \\
\hline 4. Current Ratio & $\begin{array}{l}\text { Kesanggupan membayar } \\
\text { hutang pada jangka pendek } \\
\text { yang paling tinggi dicapai } \\
\text { pada tahun } 2013\end{array}$ & $\begin{array}{l}\text { Kemapuan untuk melunasi } \\
\text { hutang lancar dapat digolongkan } \\
\text { cukup tinggi dengan nilai satu } \\
\text { rupiah dijamin Rp 1,44-1,84 }\end{array}$ \\
\hline 5. Assets Turn Over & $\begin{array}{l}\text { Tingkat efektivitas yang } \\
\text { dicapai dapat digolongkan } \\
\text { rendah dengan dilihat pada } \\
\text { tahun } 2011 \text { nilai yang } \\
\text { dicapai } 0.09 \text { kali, ini tertinggi } \\
\text { yang dapat dicapai. }\end{array}$ & $\begin{array}{l}\text { Kemampuan dana yang tertanam } \\
\text { dalam total aktiva berputar } \\
\text { dalam satu periode dibawah } 100 \\
\% \text { sehingga tingkat efektivitasnya } \\
\text { kurang baik }\end{array}$ \\
\hline 6. Net Profit Margin & $\begin{array}{l}\text { Tingkat menghasilkan laba } \\
\text { dapat mempertahankan } \\
\text { stabilitas ini terlihat pada } \\
\text { tahun } 2013 \text { mengalami } \\
\text { peningkatan. }\end{array}$ & $\begin{array}{l}\text { Kemampuan mencapai laba } \\
\text { termasuk rendah ini terlihat dari } \\
\text { setiap rupiah yang diusahakan } \\
\text { menghasilkan laba netto } 0,16 \% \\
\text { sampai dengan } 0,17 \% \\
\end{array}$ \\
\hline $\begin{array}{l}\text { 7. Rate of Return On } \\
\text { Investment (ROI) }\end{array}$ & $\begin{array}{l}\text { Tingkat investasi terjadi } \\
\text { peningkatan pada tahun } \\
2011 \text { sampai dengan tahun } \\
2013 \text {. }\end{array}$ & $\begin{array}{l}\text { Kemampuan dari dana yang } \\
\text { diinvestasikan dalam total aktiva } \\
\text { untuk menghasilkan laba netto } \\
\text { yang dicapai kurang baik karena } \\
\text { berfluktuasi, sebaiknya terjadi } \\
\text { peningkatan yang signifikan. }\end{array}$ \\
\hline
\end{tabular}

Bila dilihat dari gambar teori yang digunakan dalam melakukan anaslisis masih menggunakan metode perhitungan yang biasa dipakai dalam ilmu ekonomi konvensional, tetapi dalam pratik pelaksanaan pemutaran dana menggunakan ilmu ekonomi syariah, hal ini tampak dalam laporan keuangan ada pos mudharabah, pos bagi hasil dan pos simpanan ZIS (zakat, infaq dan shadaqah) dan mempunyai tujuan utnuk meningkatkan kesejahteraan anggota dan masyarakat umumnya. Dan pelaksanaan yang dilakukan dalam mengelola berdasarkan dengan caracara yang sesuai dalam al-Quran dan Hadis.

\section{SIMPULAN}

Jurnal Al-hikmah Vol. 13, No. 2, Oktober 2016 ISSN 1412-5382 
Kinerja keuangan yang terjadi pada pendapatan BMT Al-Ittihad Pekanbaru cukup stabil dalam hal efesiensi biaya disebabkan jika pengeluaran (biaya) operasional meningkat maka pendapatanpun meningkat dan sebaliknya jika pengeluaran (biaya) operasional menurun maka pendapatan pun menurun.

Sisa hasil usaha selama empat tahun terakhir juga dapat dipertahankan stabilitasnya seperti pada tahun 2011 laba bersih yang diperoleh relatif kecil dari tahun 2012 tetapi dibarengi dengan biaya kecil pula sehingga laba yang dihasilkan juga relatif stabil. Stabilitas sisa hasil usaha BMT Al-ittihat Pekanbaru terbukti setiap tahun meningkat, artinya pendapatan BMT AlIttihad Pekanbaru setiap tahun selalu lebih besar dari pada pengeluaran.

Kinerja Keuangan BMT Al-Ittihad Pekanbaru dalam meningkatkan penerimaannya yang bersumber dari pendapatan jasa, pendapatan lain-lain dan pendapatan administrasi dikurangi dengan pengeluaran (biaya) operasional dengan menggunakan skala prioritas mana yang harus dilaksanakan dan mana yang tidak dengan tujuan untuk memperoleh laba yang maksimal juga terbukti stabil dalam perkembangannya.

\section{DAFTAR RUJUKAN}

Achmad Ramzy Tadjoedin, dkk. 1992. Berbagai Aspek ekonomi Islam, Yogyakarta : P3EI FE UII dan Tiara Wacana.

Departemen Agama RI. 1989 Al-Quran Dan Terjemahan. Semarang : Toha Putra.

Djazuli, H.A. dan Janwari, Yadi. 2002. Lembaga-Lembaga Perekonomian Umat, Jakarta : Raja Grafindo Persada.
Harahap, Sofyan Syafri. 2002. Auditing Dalam Perspektif Islam. Jakarta : Pustaka Quantum. 2001. Akuntansi Islam, Jakarta : Bumi Aksara. , 1995. Auditing Perusahaan Kecil, Jakarta : Bumi Aksara.

Karim, Adiwarman. 2004. Bank Islam Analisis Fiqih dan Keuangan, ed.2, Jakarta : Raja Grafindo Persada.

Hery. 2012. Analisis Laporan Keuangan, Jakarta: Bumi Aksara.

Kasmir. 2010. Pengantar Manajemen Keuangan. Jakarta: Kencana Prenada Media Group.

Syamsudin, Lukman. 1998. Manjemen Keuangan Perusahaan. Jakarta: PT. Raja Grafindo Persada.

Lulail, Jamal. 2009. Manajemen Bank Syariah, Malang: UIN- Malang Press.

Mahmud M. Hanafi, Abdul Halim. 2000. Analisis Laporan Keuangan, Yogyakarta: AMP-YKPN.

Muhammad. 2000. Lembaga-Lembaga Keuangan Umat Kontemporer, Yogyakarta : UII Press.

Mulyadi. 1993. Akuntansi Biaya, ed. 5, Yogyakarta : STIE YKPN.

Rahman, Afzalur. 1996. Doktrin Ekonomi Islam, Yogyakarta : Dana Bhakti Wakaf.

Riyanto, Bambang. 1977. Dasar-Dasar Pembelanjaan Perusahaan, Yogyakarta : BPFE UGM.

Suhendi, Hendi. 2002. Fiqh Muamalah Membahas Ekonomi Islam. Jakarta : Raja Grafindo Persada.

S.R, Soemarso. 1994. Akuntansi Suatu Pengantar, ed. 4, Jakarta : Rineka Cipta.

Singarimbun, Masri. 1988. Metode Riset dan Survey, yogyakarta : PPSK UGM.

Singit Triandu, dkk. 2006. Bank dan Lembaga Keuangan Lain. Jakarta: Penerbit Salemba Empat.

Syafi'i Antonio, 2001. Bank Syariah Dari Teori Ke Praktek. 
Widodo, Hertanto. 2000. Panduan Praktis Opersional Baitul Mal wat Tamwil (BMT), Bandung : Mizan.

Widodo, Hg. Suseno Triyanto. 1990. Indikator Ekonomi, Dasar Perhitungan Ekononmi
Indonesia,cet. l, Yogyakarta : Kanisius,.

Zakiyudi. Ais. 2013. Akuntansi Tingkat Dasar, Jakarta : Mitra Wacana Media. 